\title{
Pengembangan Sistem Pendukung Outline Tugas Akhir (SPOTA) Program Studi Informatika Universitas Tanjungpura
}

\author{
All Binardo V B B ${ }^{\# 1}$, Novi Safriadi ${ }^{\# 2}$, Helen Sastypratiwi ${ }^{\# 3}$ \\ \#Program Studi Informatika Universitas Universitas Tanjungpura \\ Jl. Prof. Dr. H. Hadari Nawawi, Pontianak, Kalimantan Barat 78115 \\ lall binardo@rocketmail.com \\ ${ }^{2}$ safriadidinformatics.untan.ac.id \\ 3helensastypratiwieinformatika.untan.ac.id
}

\begin{abstract}
Abstrak- "Sistem Pendukung Tugas Akhir" (SPOTA) adalah salah satu aplikasi pendukung untuk mengatur penerimaan topik atau gagasan tugas akhir, yang digunakan di Program Studi Informatika Universitas Tanjungpura. Melalui SPOTA, mahasiswa dapat mengajukan topik tugas akhir secara online sehingga terjadi interaksi aktif antara dosen dan mahasiswa baik itu tanya jawab, arahan atau koreksi terhadap draft yang diusulkan. Aplikasi SPOTA berbasis smartphone dengan sistem operasi android telah dikembangkan dengan memanfaatkan layanan Google Cloud Messaging sebagai push notification service. Dikarenakan Google Cloud Messaging library untuk aplikasi android akan segera ditutup dan notifikasi tidak dapat lagi diterima di aplikasi yang terpasang pada ponsel pintar berbasis android penelitian ini kembali mengangkat permasalahan sebelumnya dan menerapkan mekanisme pengelompokkan judul berdasarkan kelompok keahlian serta menambahkan layanan pemberitahuan via email pada sisi backend web. Dengan dikembangkannya kembali aplikasi SPOTA untuk mengembalikan fungsi push notification yang sudah tidak dapat diakses kembali mahasiswa dan dosen dapat mengakses pemberitahuan dari aplikasi seperti komentar terbaru dan pengajuan judul terbaru, sehingga mempercepat proses review. Berdasarkan hasil pengujian, aplikasi ini sudah berjalan dengan baik pada perangkat smartphone Android, mulai dari Android versi 4.4 (KitKat) hingga Android versi 8 (Oreo). Hasil perhitungan Likert's Summated Rating untuk aplikasi dosen diperoleh nilai 507 yang menerangkan bahwa aplikasi ini dapat dikategorikan dengan kriteria "Cukup Berhasil" dan untuk aplikasi mahasiswa sebesar 887 yang menerangkan bahwa aplikasi ini dapat dikategorikan dengan kriteria "Berhasil" untuk aplikasi mahasiswa.
\end{abstract}

Kata kunci-SPOTA, push notification, Google Cloud Messaging, kelompok keahlian, aplikasi android

\section{Pendahuluan}

SPOTA merupakan sebuah sistem informasi berbasis web yang dikembangkan di Program Studi Informatika
Universitas Tanjungpura. SPOTA merupakan media komunikasi interaktif, antara mahasiswa dan dosen dalam melakukan konsultasi dan review judul tugas akhir mahasiswa yang dikembangkan oleh Rudy Tandra pada tahun 2008. Melalui SPOTA, mahasiswa dapat melakukan pengajuan topik secara online, dan dosen dapat melakukan review pada judul yang diajukan oleh para mahasiswa. Mahasiswa dan dosen dapat saling memberikan umpan balik berupa komentar pada judul yang diajukan melalui kolom komentar. Pada akhir review, dosen dapat memberikan persetujuan terhadap judul yang diajukan dan hasil persetujuan tersebut akan mejadi rujukan Ketua Program Studi dalam menentukan pembimbing dan penguji tugas akhir untuk mahasiswa bersangkutan [1].

Pada masa implementasi SPOTA pelaksanaan proses praoutline kegiatan review, pemberian umpan balik, pertanyaan maupun persetujuan oleh dosen maupun mahasiswa masih terhambat. Hal ini disebabkan tidak adanya pemberitahuan pada aplikasi SPOTA terhadap dosen maupun mahasiswa. Dengan adanya kendala ini, proses review dan pengambilan keputusan hingga pembagian pembimbing tugas akhir terhambat [2] Dengan demikian judul yang diajukan pada SPOTA akan di proses sangat lama dan menghambat seminar outline.

Untuk mengatasi kendala tersebut, SPOTA Android dikembangkan oleh Rudy Tasa Dirsa pada tahun 2015 dengan memanfaatkan layanan Google Cloud Messaging sebagai third party push notification service yang dikembangkan oleh Google. Pada tahun 2018 Google memutuskan untuk tidak lagi mengembangkan layanan Google Cloud Messaging dan merekomendasikan para pengembang beralih ke Firebase Cloud Messaging yang mewarisi infrastruktur Google Cloud Messaging dan mengubah endpoint development menjadi lebih sederhana [3]. Hal tersebut menyebabkan fitur push notification pada SPOTA tidak dapat berjalan sebagaimana semestinya. 
Pada tahun 2018 Program Studi Informatika Universitas Tanjungpura mulai menerapkan sistem pembagian tugas akhir berdasarkan kelompok keahlian sehingga seluruh usulan topik tugas akhir terbagi sesuai dengan bidang - bidang yang ada serta dapat dibimbing oleh dosen yang sesuai dengan bidang keahlian yang sesuai. Kelompok keahlian tersebut antara lain:

- Computational and Artificial Intelligence

- Informational System and Data Spatial

- Software Engineering and Mobile Computing

- Network and Security

Berdasarkan uraian diatas perlu dilakukan pengembangan pada sistem yang anda agar fitur push notification dapat kembali berjalan serta draft dapat tersaring sesuai dengan kelompok keahlian yang ada.

\section{URAIAN PENELITIAN}

\section{A. Sistem Pendukung Outline Tugas Akhir (SPOTA)}

Sistem Pendukung Outline Tugas Akhir (SPOTA) pertama kali dikembangkan pada tahun 2008 oleh Rudy Tandra dan merupakan sebuah aplikasi berbasis web dengan tujuan untuk mengatasi masalah penjadwalan seminar dan sidang serta mempersingkat pengambilan keputusan terhadap desain praoutline yang diusulkan mahasiswa [1]. Pengembangan SPOTA dilanjutkan oleh Ridwan Tasa Dirsa pada tahun 2015. SPOTA dikembangkan kembali untuk meningkatkan response time baik dosen dan mahasiswa terhadap proses review $d r a f t$ sehingga alur penerimaan draft menjadi lebih cepat. Hal tersebut dicapai dengan mengembangkan aplikasi dengan platform ponsel pintar berbasis sistem operasi Android dengan memanfaatkan teknologi push notification milik Google bernama Google Cloud Messaging Service sehingga pesan terhadap aktivitas review dapat diterima secara cepat [2].

\section{B. Kelompok Keahlian}

Program Studi Informatika Universitas Tanjungpura mulai mengimplementasikan mekanisme pengelompokkan usulan tugas akhir sesuai dengan kelompok keahlian pada tahun 2018. Topik usulan akan didistribusikan pihak program studi sesuai dengan kelompok keahlian yang kemudian pihak internal kelompok keahlian akan menentukan bila topik usulan layak untuk masuk ke SPOTA. Pada SPOTA topik usulan akan diulas oleh dosen-dosen dan mahasiswa diharapkan dapat mempertahankan topik usulan. Hasil keputusan persetujuan terhadap topik usulan serta penunjukkan pembimbing dan penguji diberikan oleh kepala program studi.

\section{Push Notification}

Push notification merupakan teknologi yang memungkinkan sebuah aplikasi untuk memberikan pesan pemberitahuan tentang pesan baru atau kejadian tanpa perlu untuk benar-benar membuka aplikasi tersebut (aplikasi berjalan pada background tray) [4]. Push notification mengizinkan aplikasi yang terintegrasi dengan pusher service untuk menerima pesan yang terkirim dari pusher server dan diterima pada aplikasi tanpa adanya campur tangan langsung dari pengguna.

Teknologi push notification akan memberitahu pengguna bila ada data baru masuk kepada pengguna dengan pembaruan yang bersifat penting dan relevan, bahkan ketika aplikasi tidak berjalan [5].

\section{Firebase Cloud Messaging Service}

Firebase Cloud Messaging merupakan solusi perpesanan lintas platform yang memungkinkan aplikasi mengirimkan pesan dan pemberitahuan ke aplikasi pengguna [6]. Firebase Cloud Messaging adalah layanan milik Google LLC yang dibangun untuk menggantikan produk sebelumnya yaitu Google Cloud Messaging sebagai teknologi pengirim push notification yang sekarang sudah bersifat multiplatform [7] dari yang sebelumnya hanya dapat berjalan pada platform ponsel pintar berbasis Android [8]. Implementasi FCM mencakup aplikasi pada server milik klien yang berinteraksi dengan server milik FCM melalui protokol HTTP atau XMPP, dan aplikasi klien (frontend). Pesan dapat ditulis dan dikirim menggunakan aplikasi server atau notification console milik FCM [9].

Google LLC mengumumkan bahwa layanan Google Cloud Messaging sudah tidak dikembangkan kembali mulai 10 April 2018 dan seluruh layanan ditutup aksesnya pada 11 April 2019 [10]. SPOTA Android memanfaatkan layanan ini sebagai third party push notification service, dengan penutupan layanan ini pengguna SPOTA Android tidak dapat lagi menerima notification message.

Firebase Cloud Messaging mewarisi infrastruktur utama dari Google Cloud Messaging dengan beberapa fitur tambahan diantaranya :

- Menambah platform yang didukung menjadi Android, IOS, dan Chrome Web Browser [3]

- Menambah fitur upstream messaging dan downstream messaging sehingga user dapat mengirim pesan kembali ke server Firebase Cloud Messaging dan sebaliknya [3].

- Mempermudah endpoint development dengan manajemen push notification message diatur oleh Firebase Cloud Messaging SDK seperti asynchronous execution dan Auto retry logic [3].

- Client token bersifat implisit yang berarti token pada sisi klien akan dibuat secara otomatis oleh Firebase Cloud Messaging SDK [3].

\section{E. RESTful Web Service}

Representational State Transfer (REST) adalah gaya arsitektur yang menetapkan batasan, berupa bentuk antarmuka, yang jika diterapkan ke layanan web menghasilkan properti yang diinginkan, seperti kinerja, skalabilitas, dan kemudahan dalam perubahan. Dalam gaya arsitektur REST, data dan fungsi-fungsi dianggap sebagai sumber daya dan diakses menggunakan Uniform Resource Identifiers (URIs), berupa tautan di web [11]. 
Sumber daya ditindaklanjuti dengan menggunakan serangkaian operasi yang sederhana dan terdefinisi dengan baik. Gaya arsitektur REST mengharuskan arsitektur dibentuk berupa arsitektur client to server dan dirancang untuk menggunakan protokol komunikasi stateless[12] melalui protokol HTTP. Ketika sumber daya tertentu diakses oleh klien, representasi dari sumber daya tersebut terhadap kondisi yang diberikan harus dikembalikan dalam bentuk response terhadap request [13]. Dalam gaya arsitektur REST, klien dan server bertukar sumber daya dengan menggunakan antarmuka yang sudah ditentukan.

\section{F. Unified Modelling Language}

Unified Modeling Language (UML) adalah pemodelan standar dalam pembuatan aplikasi berorientasi objek yang diajukan oleh Object Management Group (OMG) pada tahun 1996 [14]. UML terdiri atas banyak elemen-elemen grafis

yang digabungkan membentuk diagram [15]. Pemodelan memberikan gambaran yang jelas mengenai sistem yang akan dibangun baik dari sisi struktural ataupun fungsional [16]. UML dapat diterapkan pada semua model pengembangan, tingkatan siklus sistem, dan berbagai macam domain aplikasi [16]. Pada penelitian ini pemodelan yang digunakan antara lain :

1) Use Case Diagram: Use case diagram mendeskripsikan sebuah interaksi antara satu atau lebih aktor dengan sistem informasi yang akan dibuat. Dengan kata lain, use case diagram digunakan untuk mengetahui fungsi-fungsi apa saja yang terdapat di dalam sistem dan siapa saja yang berhak mengakses fungsi tersebut [14].

2) Class Diagram: Diagram kelas menggambarkan struktur sistem dari segi pendefinisian kelas-kelas yang akan dibuat untuk membangun sistem. Kelas memiliki apa yang disebut atribut dan metode atau operasi. Atribut merupakan variabel-variabel yang dimiliki oleh suatu kelas. Metode atau operasi adalah fungsi-fungsi yang dimiliki oleh suatu kelas [14].

3) Sequence Diagram: Diagram Sekuen menggambarkan kelakuan objek pada use case dengan mendeskripsikan waktu hidup objek dan message yang dikirimkan dan diterima antar objek. Dalam menggambarkan sequence diagram perlu memperhatikan objek-objek yang terlibat di dalam use case beserta metode-metode yang dimiliki kelas yang diinstansiasi menjadi objek itu [14].

\section{Metodologi Penelitian}

\section{A. Data Penelitian}

Bahan penelitian yang digunakan berupa data dan struktur sistem lama, serta hasil wawancara dan diskusi dengan kepala program studi tentang sistem baru. Adapun data yang dikumpulkan berupa permasalahan pesan pemberitahuan, mekanisme pengelolaan dengan kelompok keahlian serta kebutuhan akan fitur konsultasi.

\section{B. Alat Penelitian}

Alat penelitian yang digunakan berupa perangkat keras dan perangkat lunak. Perangkat keras yang digunakan yaitu :

1. Satu unit laptop ASUS X455LD dengan spesifikasi, Intel Core i3 4030U 1.9GHz, 6GB DDR3L RAM, VGA NVIDIA GEFORCE GT 820m 2GB, 128GB SSD, 500GB HDD

2. Satu unit ponsel XiaoMi Redmi Note 2 dengan spesifikasi, chipset Mediatek MT6795 Helio X10 $(28 \mathrm{~nm})$, sistem operasi Android 5.0 (Lollipop), CPU Octa-core 2.0 GHz Cortex-A53, 2GB RAM, GPU PowerVR G6200, ukuran 5.5 inch

3. Digital Ocean Droplets 1 GB Memory, 1 vCPU, 25 GB SSD, dan 1 TB transfer rate.

4. Firebase Cloud Messaging Server

Perangkat Lunak yang digunakan yaitu :

1. Linux Mint 18.3 sebagai sistem operasi

2. Visual Studio Code sebagai text editor

3. Android Studio sebagai IDE

4. Draw.io sebagai alat bantu pembuatan diagram

5. PHP 7 dengan Laravel Framework

6. Apache2 sebagai local server

7. MySQL sebagai backend database

8. Ubuntu 18.04 LTS sebagai Cloud Server OS

\section{Metode Penelitian}

Metode penelitian yang akan dilakukan akan dijelaskan pada diagram alir penelitian pada Gambar 1 .

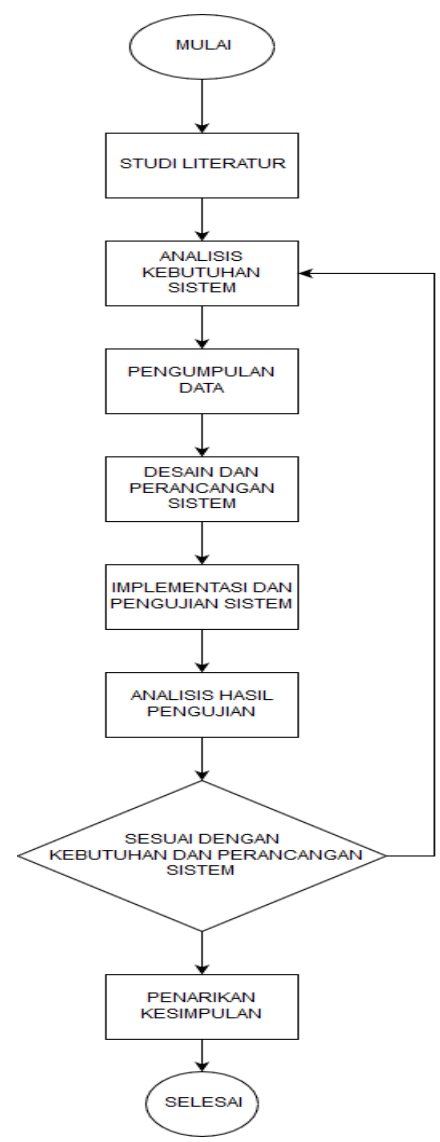

Gambar. 1 Metodologi penelitian 


\section{Arsitektur Sistem}

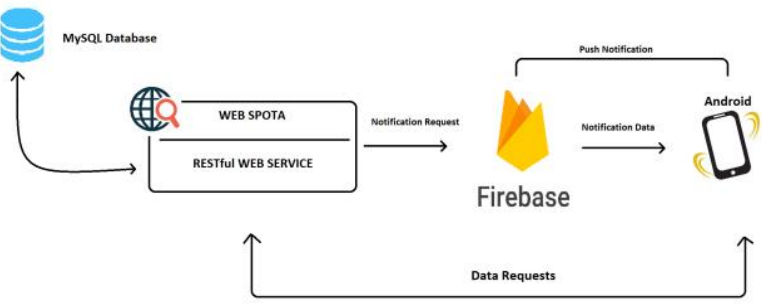

Gambar. 2 Arsitektur sistem

Arsitektur sistem dapat dilihat pada Gambar 2. Aplikasi berbasis web akan mengirimkan HTTP POST request ke Firebase Cloud Messaging Server. Request berisi client token, server key, notification body dan notification title. Setelah HTTP Request diterima oleh Firebase Cloud Messaging Server aplikasi yang sudah terpasang pada ponsel pintar berbasis Android yang telah ditandai dengan client token secara otomatis oleh Firebase Cloud Messaging SDK akan menerima pesan pemberitahuan (push notification message) sesuai dengan client token yang dikirim ke Firebase Cloud Messaging Server. Beberapa aktivitas yang dapat menghasilkan push notification pada SPOTA antara lain :

- Draft baru masuk

- Komentar pada draft

- Komentar pada konsultasi

- Penambahan Jadwal

- Penambahan Pengumuman

- Penambahan putusan terhadap draft

\section{E. Use Case Diagram}

Use Case Diagram aplikasi diperlihatkan pada Gambar 3.

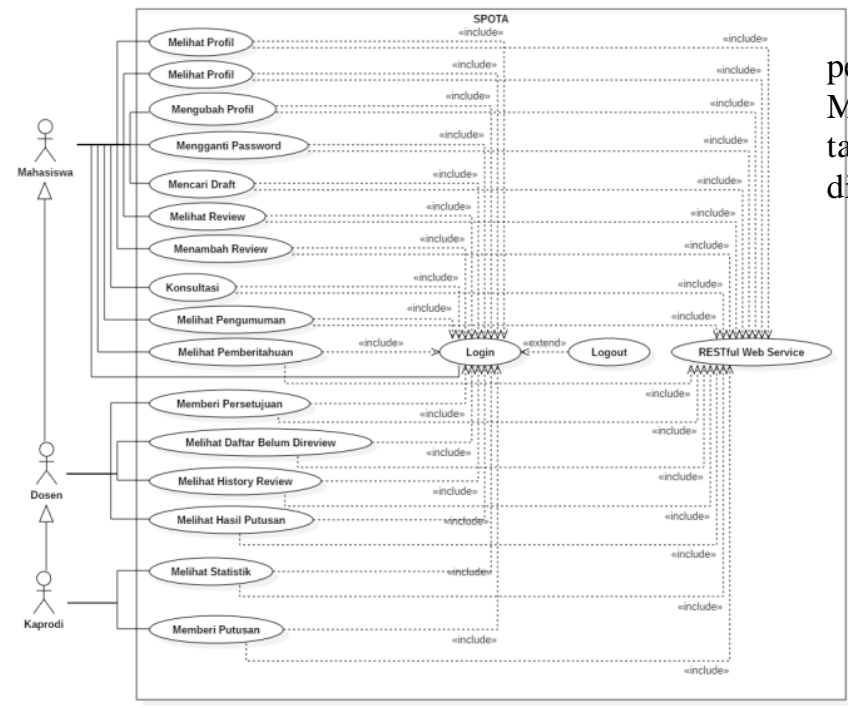

Gambar. 3 Use case diagram SPOTA android

\section{IV.HASIL PENGUJIAN DAN IMPLEMENTASI}

\section{A. Pengujian Aplikasi}

Pengujian merupakan salah satu tahapan dalam membangun sebuah perangkat lunak. Tahapan pengujian bertujuan untuk menemukan kesalahan dan memastikan apakah sistem yang dibangun sudah berjalan dengan baik dan sesuai dengan rancangan [17]. Pengujian pada aplikasi yang akan dibangun akan dilakukan dengan menggunakan metode Black Box, pengujian kompatibilitas, dan kuesioner.

\section{B. Implementasi Firebase Cloud Messaging pada Backend}

Push Notification di implementasikan dengan menggunakan HTTP v1 API yang disediakan oleh Firebase Cloud Messaging Service milik Google. Push Notification bekerja dengan memanfaatkan HTTP post request dan diletakkan di sisi backend webservice Request dikirm menuju https://fcm.googleapis.com/fcm/. Implementasi firebase cloud messaging pada backend dapat dilihat pada gambar 4

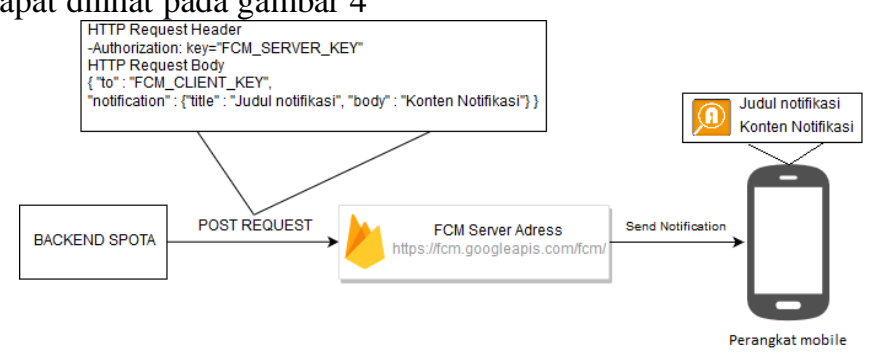

Gambar. 4 Implementasi firebase cloud messaging pada backend

\section{Hasil Aplikasi}

Aplikasi yang dipisah menjadi 2 sesuai dengan jenis pengguna yaitu aplikasi SPOTA Dosen dan SPOTA Mahasiswa. Hasil dari aplikasi dibuktikan dengan tangkapan layar (screenshot) dari aplikasi yang dapat diliht pada gambar 5-11. 
Gambar. 5 Splash screen SPOTA mahasiswa

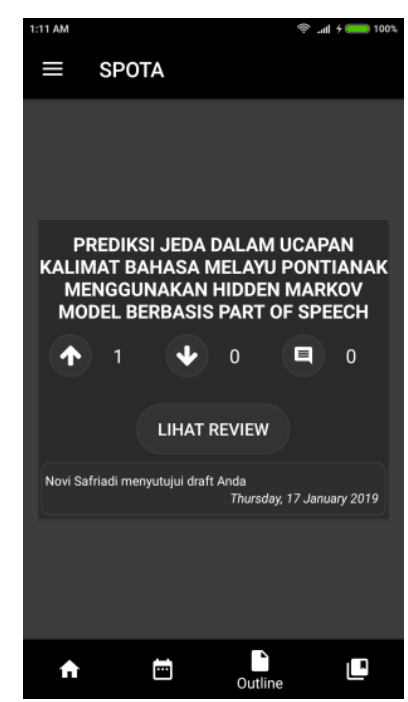

Gambar. 6 Menu outline pribadi SPOTA mahasiswa

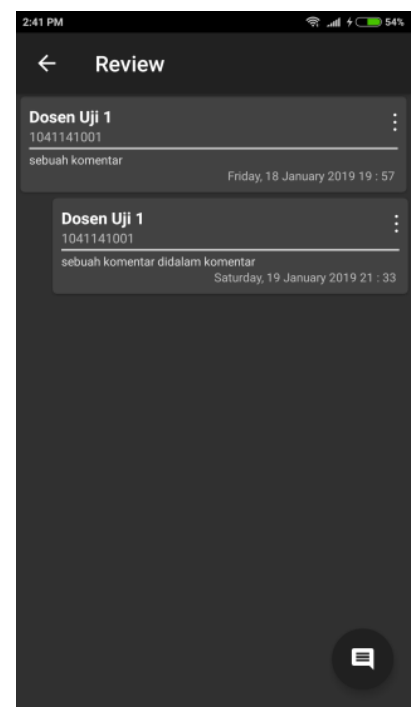

Gambar. 7 Menu review SPOTA mahasiswa

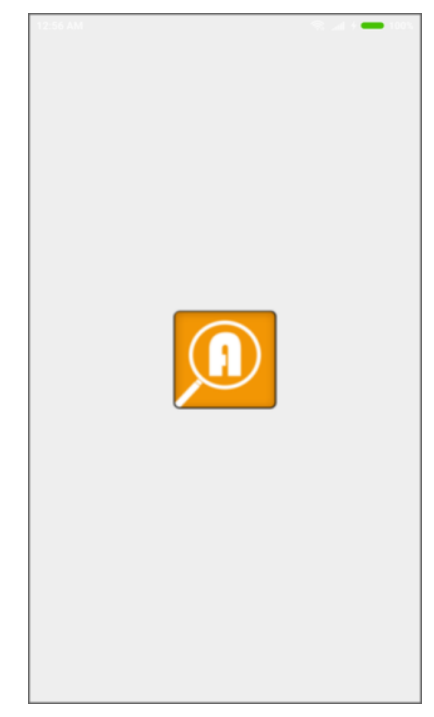

Gambar. 8 Splash screen SPOTA dosen

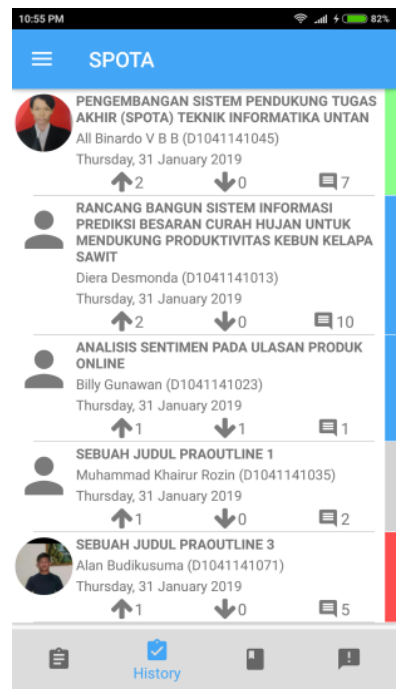

Gambar. 9 Menu histori SPOTA dosen

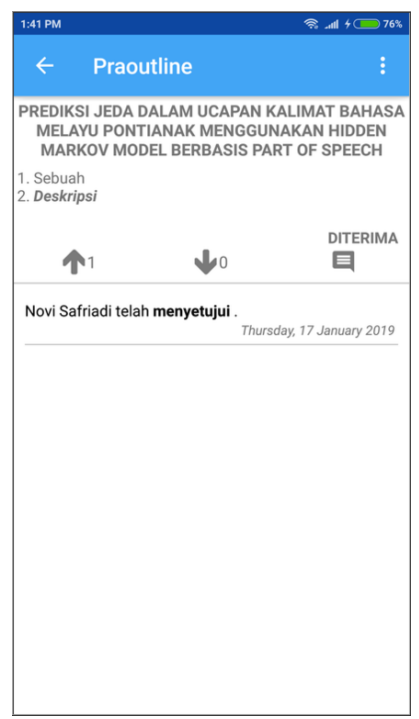


Gambar. 10 Menu praoutline SPOTA dosen

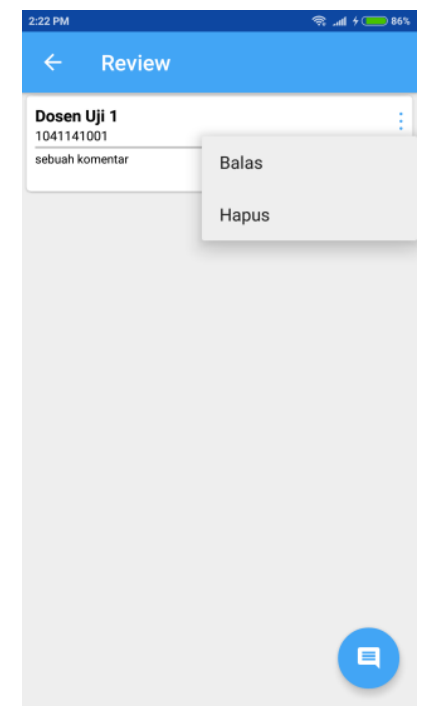

Gambar. 11 Menu review SPOTA dosen

\section{Pengujian Black Box-Robustness Testing}

Black Box Testing berfokus pada spesifikasi fungsional dari perangkat lunak. Tester dapat mendefinisikan kumpulan kondisi input dan melakukan pengetesan pada spesifikasi fungsional program [18]. Hasil pengujian blackbox - robustness testing dapat dilihat pada Tabel 1 dan Tabel 2.

TABEL I

TABel Hasil Pengujian MENu RevieW

\begin{tabular}{|l|l|l|l|l|}
\hline Masukkan & \multicolumn{2}{|l|}{ Contoh Data } & $\begin{array}{l}\text { Hasil } \\
\text { Eksekusi }\end{array}$ & $\begin{array}{l}\text { Keteranga } \\
\text { n }\end{array}$ \\
\hline $\begin{array}{l}\text { Komentar } \\
\text { kosong }\end{array}$ & Komentar & & $\begin{array}{l}\text { Pesan : } \\
\text { Isikan } \\
\text { komentar } \\
\text { anda }\end{array}$ \\
\hline $\begin{array}{l}\text { Komentar } \\
\text { terisi }\end{array}$ & Komentar & $\begin{array}{l}\text { sebuah } \\
\text { komentar }\end{array}$ & Berhasil & \\
\hline
\end{tabular}

TABEL III

Tabel Hasil Pengujian Menu Konsultasi

\begin{tabular}{|l|l|l|l|l|}
\hline Masukkan & \multicolumn{2}{|l|}{ Contoh Data } & $\begin{array}{l}\text { Hasil } \\
\text { Eksekusi }\end{array}$ & $\begin{array}{l}\text { Keteranga } \\
\text { n }\end{array}$ \\
\hline $\begin{array}{l}\text { Komentar } \\
\text { kosong }\end{array}$ & Komentar & $\begin{array}{l}\text { Pesan : } \\
\text { Field tidak } \\
\text { boleh } \\
\text { kosong }\end{array}$ \\
\hline $\begin{array}{l}\text { Komentar } \\
\text { terisi }\end{array}$ & Komentar & $\begin{array}{l}\text { sebuah } \\
\text { komenta } \\
\text { r }\end{array}$ & Berhasil & \\
\hline
\end{tabular}

\section{E. Pengujian Kompatibilitas}

Pengujian ini dilakukan dengan menginstal aplikasi pada beberapa perangkat android yang berbeda. Hasil pengujian dapat dilihat pada Tabel 3.

TABEL IIIII

HASIL UJI KOMPATIBILITAS

\begin{tabular}{|c|c|c|c|c|c|}
\hline No & $\begin{array}{l}\text { Merek } \\
\text { Smart } \\
\text { phone }\end{array}$ & Tipe & Layar & $\begin{array}{l}\text { Versi } \\
\text { Sistem } \\
\text { Opera } \\
\text { si } \\
\end{array}$ & Keterangan \\
\hline 1 & $\begin{array}{c}\text { XiaoM } \\
\text { i } \\
\text { Redmi } \\
\text { Note } 2\end{array}$ & $\begin{array}{l}\text { Smartpho } \\
\text { ne }\end{array}$ & $\begin{array}{c}5.5 \% \\
\text { resolusi : } \\
1080 \mathrm{x} \\
1920 \\
\text { pixel }\end{array}$ & $\begin{array}{l}\text { Androi } \\
\text { d } 5.0 .2 \\
\text { Lollipo } \\
\text { p }\end{array}$ & $\begin{array}{ll}\text { 1) } & \text { Instalasi : } \\
& \text { Berhasil } \\
\text { 2) } & \text { Tampilan : } \\
& \text { Sesuai } \\
\text { 3) Kinerja : } & \text { Berjalan } \\
& \text { Lancar } \\
\end{array}$ \\
\hline 2 & $\begin{array}{c}\text { Samsu } \\
\text { ng } \\
\text { Grand } \\
2\end{array}$ & $\begin{array}{l}\text { Smartpho } \\
\text { ne }\end{array}$ & $\begin{array}{l}5.25 ” \\
\text { resolusi : } \\
720 \mathrm{x} \\
1280 \\
\text { pixel }\end{array}$ & $\begin{array}{c}\text { Androi } \\
\text { d } 4.4 .4 \\
\text { KitKat } \\
\text { (telah } \\
\text { diperba } \\
\text { harui) }\end{array}$ & $\begin{array}{l}\text { 1) Instalasi : } \\
\text { Berhasil } \\
\text { 2) Tampilan : } \\
\text { Sesuai } \\
\text { 3) Kinerja : } \\
\text { Berjalan } \\
\text { Lancar }\end{array}$ \\
\hline 3 & $\begin{array}{c}\text { XiaoM } \\
\text { i } \\
\text { Redmi } \\
\text { Note } 3\end{array}$ & $\begin{array}{l}\text { Smartpho } \\
\text { ne }\end{array}$ & $\begin{array}{c}5.5 \% \\
\text { resolusi : } \\
1080 x \\
1920 \\
\text { pixel }\end{array}$ & $\begin{array}{c}\text { Androi } \\
\text { d } 5.1 .1 \\
\text { Lollipo } \\
\text { p }\end{array}$ & $\begin{array}{ll}\text { 1) } & \text { Instalasi : } \\
& \text { Berhasil } \\
\text { 2) } & \text { Tampilan : } \\
& \text { Sesuai } \\
\text { 3) Kinerja : } & \text { Berjalan } \\
& \text { Lancar } \\
\end{array}$ \\
\hline 4 & $\begin{array}{c}\text { XiaoM } \\
\text { i } \\
\text { Redmi } \\
\text { Note } 4\end{array}$ & $\begin{array}{l}\text { Smartpho } \\
\text { ne }\end{array}$ & $\begin{array}{c}5.5 \%, \\
\text { resolusi : } \\
1080 \mathrm{x} \\
1920 \\
\text { pixel }\end{array}$ & $\begin{array}{c}\text { Androi } \\
\text { d } 6.0 \\
\text { Marsh } \\
\text { mallow }\end{array}$ & $\begin{array}{ll}\text { 1) } & \text { Instalasi : } \\
& \text { Berhasil } \\
\text { 2) } & \text { Tampilan : } \\
& \text { Sesuai } \\
\text { 3) Kinerja : } & \text { Berjalan } \\
& \text { Lancar } \\
\end{array}$ \\
\hline 5 & $\begin{array}{c}\text { XiaoM } \\
\text { i } \\
\text { Redmi } \\
\text { A4 }\end{array}$ & $\begin{array}{l}\text { Smartpho } \\
\text { ne }\end{array}$ & $\begin{array}{c}5.5 ", \\
\text { resolusi : } \\
1080 \mathrm{x} \\
1920 \\
\text { pixel }\end{array}$ & $\begin{array}{c}\text { Androi } \\
\text { d } 6.0 .1 \\
\text { Marsh } \\
\text { mallow }\end{array}$ & $\begin{array}{ll}\text { 1) } & \text { Instalasi : } \\
\text { Berhasil } \\
\text { 2) } & \text { Tampilan : } \\
& \text { Sesuai } \\
\text { 3) Kinerja : } & \text { Berjalan } \\
& \text { Lancar } \\
\end{array}$ \\
\hline 6 & $\begin{array}{c}\text { Samsu } \\
\text { ng } \\
\text { Grand } \\
\text { Prime }\end{array}$ & $\begin{array}{l}\text { Smartpho } \\
\text { ne }\end{array}$ & $\begin{array}{c}5.5 \% \\
\text { resolusi : } \\
1080 x \\
1920 \\
\text { pixel }\end{array}$ & $\begin{array}{c}\text { Androi } \\
\text { d } 5.0 .2 \\
\text { Lollipo } \\
\mathrm{p} \\
\text { (telah } \\
\text { diperba } \\
\text { harui) }\end{array}$ & $\begin{array}{ll}\text { 1) } & \begin{array}{l}\text { Instalasi : } \\
\text { Berhasil }\end{array} \\
\text { 2) } & \begin{array}{l}\text { Tampilan : } \\
\text { Sesuai }\end{array} \\
& \\
\text { 3) } & \text { Kinerja : } \\
& \text { Berjalan } \\
& \text { Lancar }\end{array}$ \\
\hline 7 & $\begin{array}{c}\text { Asus } \\
\text { Zenfon } \\
\text { e Selfie }\end{array}$ & $\begin{array}{l}\text { Smartpho } \\
\text { ne }\end{array}$ & $\begin{array}{l}5.5 \% \\
\text { resolusi: } \\
1080 \mathrm{x} \\
1920 \\
\text { pixel }\end{array}$ & $\begin{array}{l}\text { Androi } \\
\text { d } 5.0 \\
\text { Lollipo } \\
\text { p }\end{array}$ & 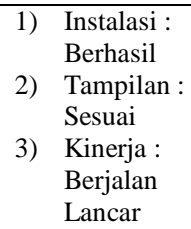 \\
\hline
\end{tabular}




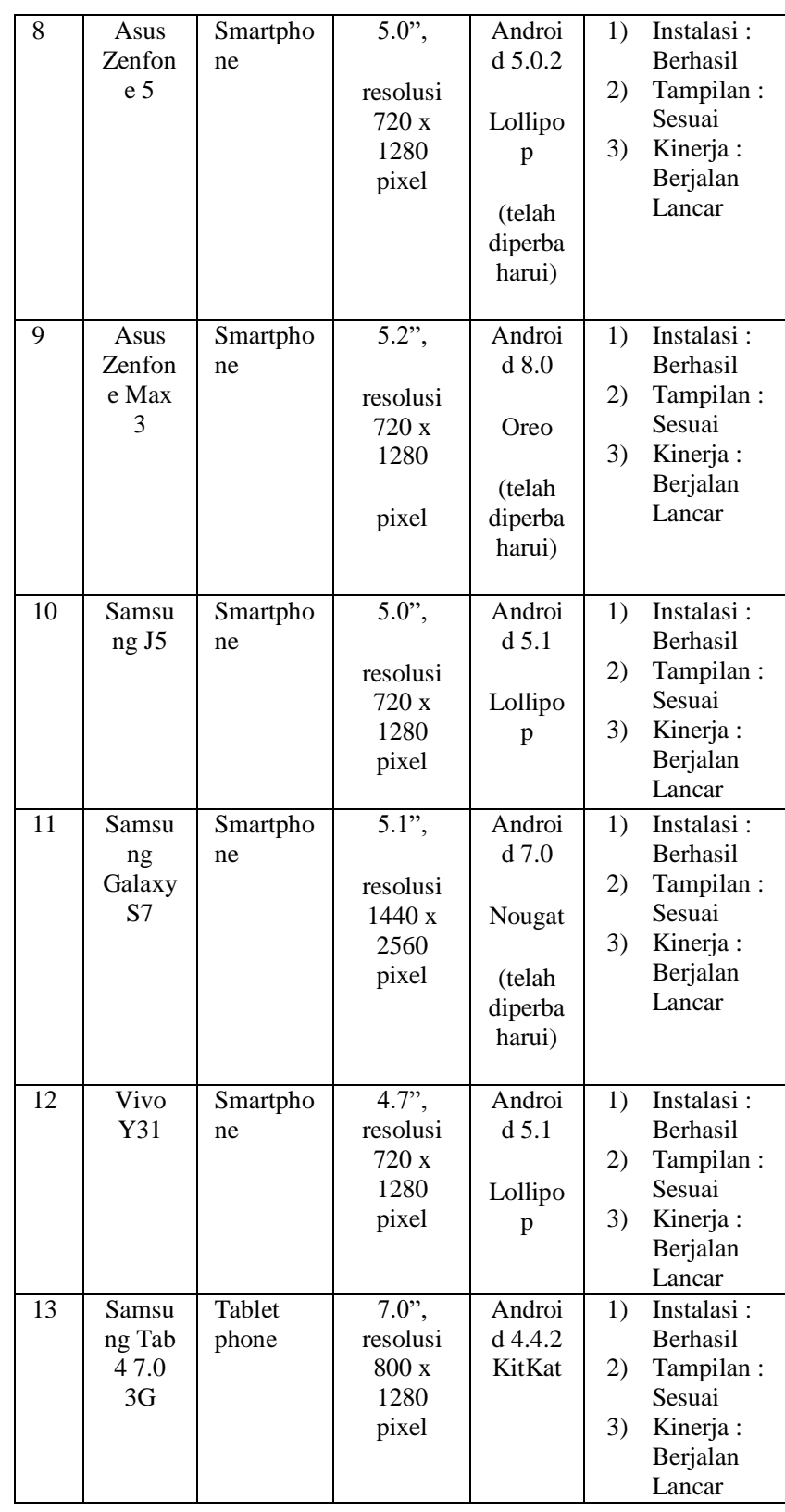

\section{F. Kuesioner}

Kuesioner yang dibagikan terdiri dari 2 tipe sesuai dengan target responden yaitu, kuesioner untuk dosen dan mahasiswa untuk masing - masing aplikasi yang sesuai dengan jenis pengguna. Untuk penilaian kuesioner diberikan nilai 1 untuk tidak baik, 2 untuk kurang baik, 3 untuk cukup baik, 4 untuk baik dan 5 untuk sangat baik.

Kuesioner yang dibagikan berisi 13 pertanyaan dan membahas 3 aspek diantaranya aspek perangkat lunak, aspek fungsionalitas dan aspek komunikasi visual. Kuesioner dibagikan kepada 10 target responden dosen dan 15 target responden mahasiswa. Total skor responden dapat dilihat pada Tabel 4 dan 5 .
TABEL IV

TOTAL SKOR RESPONDEN DOSEN

\begin{tabular}{|l|c|c|c|c|c|c|c|c|c|c|c|c|c|c|}
\hline \multirow{2}{*}{$\begin{array}{l}\text { Respo } \\
\text { nden }\end{array}$} & $\mathbf{1}$ & $\mathbf{2}$ & $\mathbf{3}$ & $\mathbf{4}$ & $\mathbf{5}$ & $\mathbf{6}$ & $\mathbf{7}$ & $\mathbf{8}$ & $\mathbf{9}$ & $\mathbf{1}$ & $\mathbf{1}$ & $\mathbf{1}$ & $\mathbf{1}$ & $\begin{array}{c}\text { Tota } \\
\mathbf{1}\end{array}$ \\
\hline $\mathrm{A}$ & 4 & 4 & 4 & 3 & 4 & 4 & 5 & 5 & 4 & 4 & 4 & 4 & 5 & 54 \\
\hline $\mathrm{B}$ & 4 & 4 & 5 & 4 & 4 & 4 & 4 & 4 & 4 & 4 & 4 & 4 & 4 & 53 \\
\hline $\mathrm{C}$ & 3 & 4 & 4 & 4 & 3 & 3 & 2 & 3 & 2 & 3 & 4 & 3 & 3 & 41 \\
\hline $\mathrm{D}$ & 4 & 5 & 4 & 3 & 4 & 4 & 5 & 5 & 4 & 4 & 4 & 4 & 5 & 55 \\
\hline E & 4 & 4 & 4 & 4 & 4 & 4 & 4 & 4 & 5 & 5 & 4 & 4 & 4 & 54 \\
\hline F & 3 & 5 & 4 & 3 & 2 & 4 & 3 & 3 & 4 & 4 & 4 & 5 & 3 & 47 \\
\hline G & 2 & 4 & 4 & 3 & 2 & 4 & 3 & 4 & 3 & 4 & 3 & 3 & 4 & 43 \\
\hline H & 3 & 4 & 4 & 3 & 3 & 3 & 4 & 2 & 3 & 3 & 3 & 3 & 4 & 42 \\
\hline I & 5 & 5 & 5 & 5 & 5 & 5 & 5 & 5 & 5 & 5 & 5 & 5 & 5 & 65 \\
\hline J & 4 & 1 & 5 & 5 & 4 & 5 & 1 & 5 & 3 & 5 & 5 & 5 & 5 & 53 \\
\hline Total & \multicolumn{10}{|c|}{} & \multicolumn{10}{|c|}{} \\
\hline
\end{tabular}

TABEL V

TOTAL SKOR RESPONDEN MAHASISWA

\begin{tabular}{|c|c|c|c|c|c|c|c|c|c|c|c|c|c|c|}
\hline \multirow{2}{*}{$\begin{array}{l}\text { Respo } \\
\text { nden }\end{array}$} & \multicolumn{13}{|c|}{ Item } & \multirow[b]{2}{*}{$\begin{array}{c}\text { Tota } \\
\text { l }\end{array}$} \\
\hline & 1 & 2 & 3 & 4 & 5 & 6 & \begin{tabular}{|l|}
7 \\
\end{tabular} & 8 & 9 & $\begin{array}{l}\mathbf{1} \\
\mathbf{0}\end{array}$ & $\begin{array}{l}\mathbf{1} \\
\mathbf{1}\end{array}$ & \begin{tabular}{|l}
1 \\
2
\end{tabular} & $\begin{array}{l}1 \\
3\end{array}$ & \\
\hline $\mathrm{K}$ & 5 & 4 & 5 & 5 & 4 & 4 & 4 & 4 & 4 & 4 & 5 & 5 & 4 & 57 \\
\hline $\mathrm{L}$ & 5 & 5 & 4 & 5 & 4 & 5 & 5 & 5 & 5 & 5 & 5 & 4 & 5 & 62 \\
\hline M & 5 & 5 & 4 & 5 & 4 & 5 & 5 & 5 & 5 & 4 & 4 & 5 & 5 & 61 \\
\hline $\mathrm{N}$ & 4 & 4 & 5 & 4 & 4 & 4 & 4 & 4 & 4 & 4 & 4 & 4 & 4 & 53 \\
\hline $\mathrm{O}$ & 4 & 4 & 5 & 5 & 4 & 4 & 4 & 5 & 4 & 4 & 5 & 4 & 5 & 57 \\
\hline $\mathrm{P}$ & 5 & 5 & 4 & 4 & 4 & 4 & 4 & 5 & 4 & 4 & 5 & 4 & 5 & 57 \\
\hline $\mathrm{Q}$ & 5 & 5 & 5 & 4 & 4 & 5 & 4 & 5 & 4 & 5 & 5 & 4 & 5 & 60 \\
\hline $\mathrm{R}$ & 5 & 5 & 5 & 5 & 4 & 4 & 5 & 5 & 4 & 5 & 4 & 5 & 5 & 61 \\
\hline $\mathrm{S}$ & 5 & 5 & 5 & 4 & 4 & 5 & 4 & 4 & 5 & 5 & 4 & 5 & 4 & 59 \\
\hline $\mathrm{T}$ & 4 & 5 & 5 & 5 & 4 & 5 & 4 & 4 & 5 & 5 & 4 & 5 & \begin{tabular}{|l|}
5 \\
\end{tabular} & 60 \\
\hline $\mathrm{U}$ & 5 & 5 & 4 & 5 & 5 & 5 & 5 & 4 & 4 & 5 & 5 & 5 & 5 & 62 \\
\hline $\mathrm{V}$ & 5 & 5 & 5 & 4 & 5 & 5 & 5 & 5 & 4 & 4 & 4 & 4 & 5 & 60 \\
\hline $\mathrm{W}$ & 5 & 4 & 4 & 5 & 4 & 4 & 4 & 4 & 5 & 4 & 4 & 4 & 5 & 56 \\
\hline $\mathrm{X}$ & 5 & 4 & 5 & 5 & 5 & 5 & 5 & 4 & 4 & 4 & 5 & 4 & 4 & 59 \\
\hline $\mathrm{Y}$ & 5 & 5 & 5 & 5 & 5 & 4 & 5 & 4 & 5 & 5 & 5 & 5 & 5 & 63 \\
\hline Total & & & & & & & & & & & & & & 887 \\
\hline
\end{tabular}

\section{G. Analisis Hasil Pengujian}

Rincian analisis pengujian aplikasi SPOTA berbasis android yang telah dilakukan dapat dirumuskan dalam poin sebagai berikut:

1. Secara keseluruhan robustness testing menunjukkan bahwa aplikasi dapat menangani proses input data dan memberikan respon dengan baik pada proses login, ubah profil, review, dan konsultasi.

2. Hasil pengujian kompatibilitas menunjukkan kedua aplikasi mahasiswa dan dosen dapat berjalan lancar pada smartphone dengan versi android KitKat (versi 4.4), Lollipop (versi 5.0, 5.0.2 dan 5.1.1), 
Marshmallow (versi 6.0 dan 6.0.1), Nougat (versi 7.0) dan Oreo (versi 8.0).

3. Berdasarkan hasil pengujian kompatibilitas aplikasi, diperoleh hasil tampilan aplikasi dapat berbeda ditiap perangkat dilihat dari ukuran dan resolusi layar tetapi tetap dapat menampilkan data secara baik.

4. Hasil pengujian kuesioner yang diukur dengan metode Likert's Summated Rating (LSR) menunjukkan untuk aplikasi dosen, responden menilai aplikasi yang dibangun dengan "cukup baik" dengan skor 507, dan untuk aplikasi mahasiswa, responden menilai aplikasi yang telah dibangun dengan "sangat baik" dengan skor 887 .

\section{KESIMPULAN}

1. Firebase Cloud Messaging HTTP v1 API telah diimplementasikan di backend webservice sebagai jalur komunikasi antara backend webservice dan Firebase Cloud Messaging server.

2. Draft usulan yang diunggah memiliki klasifikasi kelompok keahlian.

3. Berdasarkan hasil pengujian, aplikasi dapat digunakan oleh pengguna baik mahasiswa dan dosen untuk melakukan aktivitas review dan konsultasi.

4. Berdasarkan pengujian kompatibilitas aplikasi dapat berjalan baik pada versi android 4.4 (KitKat) hingga 8 (Oreo)

5. Hasil kuesioner yang dihitung dengan metode Likert's Summated Rating menunjukkan bahwa aplikasi dosen dinilai cukup berhasil dan mahasiswa berhasil.

\section{REFERENSI}

[1] R. Tandra, Implementasi Sistem Pendukung Outline Tugas Akhir Program Studi Teknik Informatika Jurusan Teknik Elektro Fakultas Teknik UNTAN. Pontianak : Universitas Tanjungpura 2008.

[2] D. Ridwan Tasa, Rancang Bangun Aplikasi Sistem Pendukung Outline Tugas Akhir (SPOTA) Program Studi Teknik Informatika Universitas Tanjungpura Berbasis Android. Jurnal Sistem dan Teknologi Informasi (JUSTIN) Vol. 3, No. 2, 2015.

[3] Migrate a GCM Client App for Android to Firebase Cloud Messaging. 2018. Google Cloud Messaging. Google Developers. https://developers.google.com/cloud-messaging/android/androidmigrate-fcm/. Diakses tanggal 18 November 2018

[4] Cambridge Dictionary. Push Notification. https://dictionary.cambridge.org/us/dictionary/english/pushnotification/. Diakses pada 11 November 2018.

[5] E. Isikligil, S. Samakay, \& D. Kılınç, A Prototype Framework for High Performance Push Notifications. International Journal of Computer Applications Vol. 166, No. 1 (Mei 2017), 2017.

[6] M. Ilhami, Pengenalan Google Firebase untuk Hybrid Mobile Apps Berbasis Cordova. Jurnal IT, 2017.

[7] S. Gupta, \& B. Kapoor, Firebase In App Development. International Research Journal of Engineering and Technology (IRJET) Vol. 3, Issue 12 (Desember 2016) , 2016

[8] Y.S. Yilmaz, B.I. Aydin, \& M. Demirbas, Google Cloud Messaging (GCM) : An Evaluation. IEEE Global Communication Conference doi:10.1109/GLOCOM.2014.7037233, 2014.

[9] N. Srivastava, U. Shree, N.R. Chauhan, \& D.K. Tiwari, Firebase Cloud Messaging (ANDROID). International Journal of Innovative Research in Science, Engineering and Technology (IJIRSET) Vol. 6, Special Issue 9 (Mei 2019), 2017.
[10] Cloud Messaging, Google Cloud Messaging. Google Developers. https://developers.google.com/cloud-messaging/. Dikases tanggal 18 November 2018, 2012.

[11] Oracle Docs, 2013. What are RESTful Web Services ?. Oracle's Documentation.

https://docs.oracle.com/javaee/6/tutorial/doc/gijqy.html/. Diakses tanggal 11 November 2018.

[12] V. Kumari, Web Services Protocol : SOAP vs REST International Journal of Advanced Research in Computer Engineering \& Technology (IJARCET) Vol. 4, Issue 5 (Mei 2015), 2015.

[13] G.D.A. Guardia, L.F. Pires, R.Z.N. Vêncio, K.C.R. Malmegrim, C.R.G. de Farias, A Methodology for the Development of RESTful Semantic Web Services for Gene Expression Analysis. PLOS ONE, doi:10.1371/journal.pone.0134011, 2015.

[14] A. S. Rosa, dan M. Shalahuddin, Rekayasa Perangkat Lunak Terstruktur dan Berorientasi Objek. Bandung : Informatika Bandung, 2013

[15] P. Irfansyah, dan S. Haryono, Model E-Commerce Produk Daur Ulang Bank Sampah Menggunakan UML. Jurnal Edukasi dan Penelitian Informatika (JEPIN) Vol. 3, No. 2, 2017.

[16] I. Akil, Rekayasa Perangkat Lunak dengan Model Unified Process. Jurnal Pilar Nusa Mandiri Vol. XII, No.1, 2016.

[17] A. Sabda Tegar, Rancang Bangun Aplikasi Kampanye Berbasis Crowdsouring. Pontianak : Universitas Tanjungpura, 2018

[18] M.S. Mustaqbal, R.F. Firdaus, \& H. Rahmadi, Pengujian Aplikas Menggunakan Black Box Testing Boundary Value Analysis (Studi Kasus : Aplikasi Prediksi Kelulusan SMPTN). Jurnal Ilmiah Teknologi Informasi Terapan (JITTER) Volume 1, No. 3 (10 Agustus 2015), 2015. 